\title{
探究计算机软件开发技术的应用与发展
}

唐瑗

云南经济管理学院

DOI:10.32629/jief.v2i4.1183

[摘 要] 计算机软件开发技术变得越来越成熟，在开发中能够结合客户的需求进行定向开发，使开发的功能更加全面有效，并且在后期的使 用便于进行维护及管理。当前计算机软件开发技术的发展领域逐渐拓宽, 为了更好地满足社会的发展需求, 应对计算机软件开发技术进行创 新，使其能够在未来的应用中具有更好的效果。

[关键词] 计算机软件开发技术; 应用; 发展

中图分类号: TP311.52 文献标识码: A

计算机软件能够给人们的生活及工作等带来便利的条件, 在信息化 技术的普及下, 计算机软件开发技术得到了改善。在计算机软件开发过 程中, 通过有效运用计算机软件开发技术, 能够提升软件开发的效率以 及质量, 使开发技术发挥出有效的作用。因此, 应对当前的计算机软件 开发技术应用进行分析, 使其在发展中更加成熟, 为计算机软件开发行 业提供更好的条件。

\section{1 计算机软件开发技术的重要性}

计算机软件开发能够促进网络技术的发展, 通过开拓计算机软件开 发能够使计算机在当前的时代背景下得到更加广泛的应用, 对信息化技 术的发展有着积极的影响。计算机软件开发能够带来具有更多功能的软 件, 使人们的需求得到满足。因此, 计算机软件开发技术在信息化技术 发展中具有重要的意义, 计算机软件开发企业应把握机会, 积极面对挑 战, 承担相应的责任, 给用户提供更加良好的体验, 使计算机软件开发 技术的发展能够为我国的信息化技术创新带来更大的空间。

\section{2 计算机软件开发方式}

2.1 原型化

计算机软件开发中, 原型化软件开发方式原理是开发者结合系统的 要求进行总结, 将此作为原型开发另一个软件。在系统运行的时候, 对 数据进行分析, 进行适当的调整, 使该软件的功能能够符合用户的使用 需求。原型化计算机软件开发思路使计算机软件开发技术服务功能有效 体现出来, 这种方式具有低投入高收益的特点。但是在大型系统开发中 应用后期维护存在着较大的难度。

\section{2 自动系统开发}

自动系统开发的方式相比其他的方法过程更加具体化, 在开发初期 阶段人员已经对内容、目的以及要求等内容全面了解, 并且制定了软件 设计开发执行方案。客户能够对软件的功能以及要求等有一定的了解, 能够避免在开发完成之后与开发企业之间产生矛盾, 开发人员可根据客 户的需求以及倾向进行开发, 在其中添加所需的功能, 使软件开发具有 人性化的特点。

\section{3 生命周期法}

生命周期法应用比较广泛, 在开发复杂的软件的时候, 利用这种方 式有着较大的优势, 开发的软件有着整体性的特点。在开发中将过程分 成了两个部分, 首先是开发阶段, 其次是维修阶段, 能够使软件的可操 作性加强, 使开发变得更加便捷。但是这种方式在应用中所需的成本比 较高, 周期比较长, 在开发前提产生了问题的时候, 会对之后的工作产 生不良的影响。

\section{1 网络化发展趋势}

计算机软件开发对互联网有着较高的要求, 网络化成为了计算机开 发技术应用的主要发展趋势。互联网能够为计算机软件的开发提供相应 的平台, 在依附于网络的过程中能够促进互联网的快速发展。将计算机 软件开发技术与互联网结合起来能够使软件的应用范围扩大, 借助互联 网的支持来实现更多的功能, 这样可使计算机软件开发的未来发展有更 好的保障, 进一步提升计算机软件的水平。

3.2 服务型发展趋势

为了给软件开发用户提供良好的服务, 计算机软件开发行业应重视 服务性特点, 使其成为未来计算机软件开发行业的发展趋势。计算机软 件开发工作应将服务终端软件使用客户作为开发面向对象, 结合客户的 需求进行软件优化, 提升软件开发人员的服务意识水平, 使计算机软件 在使用性能以及设计等方面都能符合客户的要求, 体现出软件开发的服 务效果。

3.3 智能化发展趋势

计算机软件开发技术在未来发展中会呈现出更强的智能化特点, 电 子机器智能化的普及成为了当前的主流形式, 计算机软件开发人员可通 过变换软件编程算法的方式来实现软件开发的智能化特点。在计算机软 件开发智能化发展的深入下, 更多的计算机软件能够具备与人类同等的 逻辑思维推理思维能力, 使计算机软件的功能更加变得更加丰富, 为计 算机软件行业的发展带来相应的动力。

\section{4 结语}

计算机软件开发技术的创新对计算机软件行业的发展有着重要的意 义, 通过对计算机软件开发技术进行合理应用, 可使计算机软件开发工 作全面改善, 保证开发过程的顺利以及最终的开发效果符合要求。在未 来的发展中, 计算机软件技术应具备网络化、智能化的特点, 还应重视 服务的效果, 使软件能够满足更多人的需求。通过对计算机软件开发技 术水平的提升，可使我国计算机软件行业的发展速度加快。

\section{[参考文献]}

[1] 姬晓鹏. 计算机软件开发技术与设计探究 [J]. 电子测 试,2020(16):133-134.

[2]王莉莉.基于分层技术的计算机软件开发分析[J].信息技术与信 息化,2020(07):41-43.

[3] 李靖.分层技术在计算机软件开发中的应用[J]. 通讯世 界,2020,27(06):33+35.

[4]穆红涛.计算机软件开发语言与分层技术的运用浅析[J].计算机 产品与流通,2020(08):27-28.

\section{3 计算机软件开发技术的未来发展趋势}

